\title{
Appraisal of Aids as Provided by Rule 225 (Council Regulation (EC) No. 1698/2005) in Tuscany Region-Methodology, Procedures and Results ${ }^{* \#}$
}

\author{
Roberto Fratini, Enrico Marone, Gabriele Scozzafava \\ Department of Agricultural and Forest Economics, Engineering, Sciences and Technologies, \\ University of Florence, Florence, Italy \\ Email: roberto.fratini@unifi.it, enrico.marone@unifi.it, gabriele.scozzafava@unifi.it
}

Received July 31 ${ }^{\text {st }}$, 2012; Revised September $5^{\text {th }}$, 2012; Accepted September $20^{\text {th }}, 2012$

\begin{abstract}
The purpose of this paper is to illustrate a methodology to determine the lost revenue and increased costs resulting from the assumption of forest-environment commitments, as provided by rule 225 (Council Regulation (EC) No. 1698/2005) of the measure defined by the Tuscany Region. The aim is therefore to determine the appropriateness of the payments provided by European Community measures. Regulation (EC) No. 1698/2005 regards mainly land management and contributes to sustainable development by encouraging farmers and forest holders to employ methods of land use compatible with the need to preserve the natural environment and landscape and protect and improve natural resources. This Rule covers support for non-productive investments linked to the achievement of agro or forest-environmental commitments or the achievement of other agri-environmental objectives, as well as measures aimed at improving forestry resources with an environmental objective (support for the first forestation of agricultural land, establishment of agroforestry systems or restoring forestry potential and preventing natural disasters). We have worked by analyzing each of the commitments required by individual actions and checking their impact on forest regional management; we have calculated the additional costs and the lost revenue resulting from the assumption of commitments.
\end{abstract}

Keywords: Forest Policy; Utilization Forest Costs; Financial Analysis

\section{Introduction}

The purpose of this paper is to illustrate a methodology to determine the lost revenue and increased costs resulting from the assumption of forest-environment commitments, as provided by rule 225 (Council Regulation (EC) No. 1698/2005) of the measure defined by the Region of Tuscany. The aim is therefore to determine the appropriateness of the payments stipulated by European Community measures.

Regulation (EC) No. 1698/2005 regards mainly land management and contributes to sustainable development by encouraging farmers and forest holders to employ methods of land use compatible with the need to preserve the natural environment and landscape and protect and improve natural resources. This regulation covers support for non-productive investments linked to the achievement of agro- or forest-environmental commitments or the achievement of other agro-environmental objectives, as well as measures aimed at improving forestry resources with an environmental objective (support for the first forestation of agricultural land, establishment of agroforestry systems or restoring forestry potential and preventing natural disasters) (OECD, 2011).

\section{Adopted Methodology}

We have worked by analyzing each of the commitments re-

*This research was sponsored by Tuscan Region.

\# A synthesis of this paper was presented to the IUFRO conference, Viterbo, Italy, 19-21 May 2011. quired by individual actions and through a check of their impact on forest regional management; we have calculated the additional costs and the lost revenue resulting from the assumption of these commitments. In any case we have the adoption voluntary of practices that go beyond the normal standards of management, or beyond the obligations set by existing environmental rules and constraints and for this, there is no quantitative evidence in ordinary forest management for resulting in a difficult to quantify the economic cost.

All calculations have been reported to the additional operations provided by Measure 225 compared to a state of welldefined and fixed baseline.

In addition, the calculation has been made by reference to Tuscan Forest Inventory, which clearly outlines the regional composition of the stands. We also made an appraisal of the value of timber production through the weighted means of timber assortments and of mean annual increment.

For the assessment of costs incurred by the forest owner, and thus the subsequent justification for the subsidies, we started from the consideration that the commitments in most cases represent an evident loss of wood and in an increase of costs related to longer time management and organization of the forest site and above all in a higher cost of logging.

For the determination of aids on the basis of standard assumptions, we have distinguished three ways of calculating the adequacy of the premium considering the scale of production and related charges between ordinary forest management and another burdened with additional commitments: 
1) The commitments act on production costs (processing) only.

2) The commitments act on revenues only.

3) The commitments act on both costs and revenues.

For greater reliability in the calculation of lost revenue and higher costs, however, it is appropriate to justify the aid in proportion to the actual costs incurred and documented individually. In this case we must, in principle however, distinguish between the expenses that have a direct impact and those that are deferred to the end of cycle.

For additional commitments with direct effects and for assessing the sufficiency of the contributions provided, we will mainly relate to the costs for the implementation of foreseen activities. As for the lost revenue related to "forest-environment" activities which directly affect aspects, they must be considered strictly related to the loss in value of the technological production of the timber.

Therefore, for any type of forest-environment commitments, whether those that have direct effects on the costs or those that impact deferred income at the end cycle, the stumpage value (SV) will be influenced, directly or indirectly.

It must be made clear that, as with the value of stumpage, which is codified by forest appraisal theory and widely adopted in forest practice (starting price for the sale of timber); it represents, in fact, a transformation value of the forest production. In practice, stumpage value is calculated as the present value of the difference between the probable revenues from the sale of wood and the costs required for its use.

In the case we would assume the stumpage value (SV) as a proxy of the Gross Margin we should assess SV without considering fixed costs; in order to comply with EU guidelines economic factors/income attributable to fixed costs should not be included in the calculation.

Gross margin per unit to be used in the calculation of adequacy of the premium must therefore consider only the costs attributable to production (specific costs), excluding all those cost items related to the structure and business organization (fixed costs). The exclusion of these last items of expenditure fully corresponds to the technical services of the European Commission (Article 53, paragraph 2 - e) of Regulation (EC) 2006/1974.

The asset of budget of the production process is defined as gross output (GO), obtained as a sum of sales value (quantity sold multiplied by the market price of wood), the value of secondary production and the value of products reutilized in other production processes (reinvestment). The value of these products is determined by applying the unit value that coincides with probable market value made by the same assortment.

Stumpage value means the value of standing trees, and therefore represents the economic results obtained (in terms of "ordinariness" or additional commitments to the ordinary), from the partial budget of forest utilization, comparing the proceeds from the sale of wood products (active) with the costs for forest operations (passive).

$$
\mathrm{SV}=\mathrm{R}-\mathrm{C}
$$

where: $\mathrm{SV}=$ the stumpage value $(€), \mathrm{R}=$ revenues from sale of forest assortments, $\mathrm{C}=$ total costs (derived by forest utilization).

In this case, we compare the stumpage value considered in an ordinary situation (i.e. the baseline) (SV) with stumpage value resulted from the activities under each measure $225\left(\mathrm{Vm}^{*}\right)$; is sufficient, for doing this comparison, to consider the individual effects on revenues and costs necessary to accomplish this activity.
In fact, $\mathrm{SV}^{*}$ differs from the $\mathrm{SV}$ as implementation of individual actions will cause a change in $\mathrm{R}$ and/or $\mathrm{C}$ according to the Formula (2):

$$
\mathrm{SV}^{*}=\left(\mathrm{R} \pm \mathrm{R}^{*}\right)-\left(\mathrm{C} \pm \mathrm{C}^{*}\right)
$$

where $\mathrm{R}^{*}$ and $\mathrm{C}^{*}$ are the specific costs arising from the nth intervention

Therefore, a comparison of the initial situation with that arising from application of individual actions foreseen by Measure $225\left(\mathrm{SV}-\mathrm{SV}^{*}\right)$ is solved considering only the effects $\pm R^{*}$ and $\pm C^{*}$ attributable to the other specific operations necessary to be in compliance with the guidelines.

Given this, compared to the initial situation that derives from the application of the individual actions required by 225 (SV $\mathrm{SV}^{*}$ ), we should first define only the effects of $\pm \mathrm{R}^{*}$ and $\pm \mathrm{C}^{*}$.

$$
\mathrm{SV}-\mathrm{SV}^{*}=\mathrm{R}-\mathrm{C}-\left(\mathrm{R} \pm \mathrm{R}^{*}\right)-\left(\mathrm{C} \pm \mathrm{C}^{*}\right)= \pm \mathrm{R}^{*} \pm \mathrm{C}^{*}
$$

In this regard, Table 1 shows the effects on $\mathrm{R}^{*}$ and $\mathrm{C}^{*}$ arising from the adoption of individual actions.

In the following we analyze in detail some of the most significant actions in order to improve the forest estate.

\section{Analysis and Results}

Calculation of lost revenue and of higher costs for individual measures adopted.

a) i. Release, of one or more plants per hectare selected from among older species and/or of greater diameter and wood value, identified according to the criteria defined in Art. No. 12 of DPGR 2003/48 / Region of Tuscany.

Baseline: on the occasion of forest cutting equal to or greater than one hectare, both in high forests and coppices, for every hectare of forest cut at least one plant per hectare must be left standing. The specimens to be released are those of the greatest diameter on the area to be cut, as indicated by the Forestry Regulations of Tuscany (DPGR No. 48/A of 08/08/2003, Article 12, paragraph 6 .

Effect on revenue component $\left(\mathrm{R}^{*}\right)$ : Loss of income derived from non-sale of timber assortments.

Effect on cost component $\left(\mathrm{C}^{*}\right)$ Increased costs for forest utilization and setting up of organization; loss of interest on invested capital (growing stock) ${ }^{1}$.

For this determination we utilized yield tables relative to the stands that are typical in Tuscany (this criterion refers to the area forest inventory). We chose precisely those tables and classes of fertility which best reflect the production characteristics of these stands.

The plant of the largest size was selected considering the customary rotation of the forest species in question; after we computed total yield by the average diameter and height of dominant plants and applied an appropriate dendrometric form factor. These parameters are normally set out with production tables (or Yield table).

Then we considered the average stumpage price by reference to prices published in a specialized Journal (www.rivistasherwood.it/tecniko-pratiko/).

When it was not possible to find the prices of wood products

${ }^{1}$ Technical operations chosen from among aged forest specimens and/or those of greater diameter and/or greater wood value, with preference to those with nest cavities useful for birds. 
Table 1.

Examination of individual actions included in 225 measures.

\begin{tabular}{|c|c|c|}
\hline Selection of forest species subject to utilization & Effects on revenues & Effect on costs \\
\hline $\begin{array}{l}\text { 1) Release of one or more plants per hectare selected from those belong- } \\
\text { ing specially older and/or greater diameter and/particularuy value, prefer- } \\
\text { ring the eldest plant with cavity-nest for birds. }\end{array}$ & $\begin{array}{l}\text { Loss of income resulting from } \\
\text { no timber use }\end{array}$ & $\begin{array}{l}\text { Increased of cost for setting orgnization, } \\
\text { higher cost of forest utilization and for } \\
\text { GPS marking }\end{array}$ \\
\hline $\begin{array}{l}\text { 2) Release of at least } 5 \text { plants per hectare selected from those belonging to } \\
\text { the species considered sporadic, and identified according to the criteria } \\
\text { defined in 'article No } 12 \text { of DPGR 48/R; 08/08/2003. }\end{array}$ & $\begin{array}{l}\text { Loss of income resulting from } \\
\text { no timber use }\end{array}$ & $\begin{array}{l}\text { Increased of cost for setting orgnization, } \\
\text { higher cost of forest utilization and for } \\
\text { GPS marking }\end{array}$ \\
\hline $\begin{array}{l}\text { 3) Exploitation in coppice and high forest of different species of pine } \\
\text { (Maritime pine and Black pine, etc.) and of coniferous trees all dried up } \\
\text { without commercial value and high-flammability; }\end{array}$ & & $\begin{array}{l}\text { Additional cost for cutting, haul and } \\
\text { disposal of woody material }\end{array}$ \\
\hline $\begin{array}{l}\text { Cleaning and mowing grass and shrub vegetation in the forests and } \\
\text { other measures for the protection of biodiversity structure. }\end{array}$ & Effects on revenues & Effect on costs \\
\hline $\begin{array}{l}\text { Cutting the shrubs in open areas within forests or wooded areas treated or } \\
\text { adjacent to a forest. }\end{array}$ & & Cost of slashing \\
\hline Management of waste processing forest utilization & Effects on revenues & Effect on costs \\
\hline $\begin{array}{l}\text { Obligation to remove or, alternatively, the obligation to chipping and/or } \\
\text { chopping, resulting in distribution on the ground, of the residues from } \\
\text { forest operations; ban on burning of waste wood. }\end{array}$ & $\begin{array}{l}\text { Sale of wood chip in large } \\
\text { sacks }\end{array}$ & $\begin{array}{l}\text { Cost of chipping, chopping, or distributing } \\
\text { of slash on the ground }\end{array}$ \\
\hline
\end{tabular}

directly, the analytical calculation of the costs of forest utilization was carried out, at the same time utilizing the evaluations of wood prices from other appraisals.

After determining the average stumpage price we multiplied it by the percentage of timber assortments gotten from the plant released in order to estimate the loss of income; to this value we added an additional share needed for identification and georeferencing of plants as previously explained. Funding measures will be provided in seven years, so it is possible that the landowners might anticipate some of the costs, at the same time it is possible that the Regional Administration may grant an advance payment to the landowners because the intervention is performed at the end of the period. The eventual interests, active or passive, that might arise are assumed to be irrelevant and so they were not considered in the calculation. Moreover, it is necessary to distinguish between landowners applying the measure at the beginning or at the end of the period considered; normally this behavior involves much higher costs for testing operations (verification) of forest setting, much higher than the currency interest on advances.

For a more completed assessment of lost revenues and higher costs of this action we have considered the economic characteristics of main stands of Tuscany and principally the values of different wood assortments. In conclusion, the stumpage value is calculated for each plant identified in the forest (the average value is considered for forests that have different classes of fertility). The values identified are weighed according to the surface distribution of the different stands in the region (source: Forest Inventory of the Region of Tuscany, 1986), obtaining a weighted average value representative of Tuscan forest land.

The action does not provide for a financial contribution for different forest types, but a weighted average value; in this case, considering the different stands and surfaces, as highlighted in Table 2, corresponds to €76.96 per plant. The lost revenue and higher costs calculated for this intervention, therefore, will amount to $€ 10.99$ per plant per year (€ 76.96:7).

a) ii. Release of at least 5 plants per hectare selected from those belonging to the species considered sporadic, and identi- fied according to the criteria defined in article No. 12 of DPGR 48/R ; 08/08/2003.

Baseline: When cutting in coppice and high forest the isolated plants of the forest species listed in paragraph 1 of article No.12 of Forestry Regulations of Tuscany must be preserved, i.e., when the density of plants is less than twenty plants per hectare for each species, and having a diameter greater than 8 $\mathrm{cm}$; subject to paragraphs 2 through 5 of that article.

Effect on revenue component $\left(\mathrm{R}^{*}\right)$ : Loss of income derived from non-sale of timber assortments.

Effect on cost component $\left(\mathrm{C}^{*}\right)$ Loss of interest on invested capital (growing stock; costs for technical operations for identification of individual plants) that consist of plant identification by GPS geo-referencing.

The operation requires that the forest thinning or final cutting, when the density of the forest exceeds the minimum, defined in Article 12 Forestry Regulations of Tuscany, leaving from a minimum of 5 to a maximum of 10 plants per hectare in addition to the baseline Tuscan Forestry Regulations. The plants left must be chosen from among the sporadic species (cited in the article) and identified according to the criteria defined therein.

Since it is not possible to make a prediction for each species considered in order to determine the lost revenue due to the lost sale of sporadic plants left in the forest, we proceeded to estimate the possible value. After the choice of 10 plants with a prevalence of the most representative species of Tuscan sylvicolture, we calculated the volume in cubic meters) using a double entry yield table. Finally, after creating the scale of plants considered we computed the average stumpage value of timber assortments: saw logs, pulp logs, firewood, etc. utilizing timber prices published in the specialized literature (Tecniko Pratiko, 2009).

To quantify the lost revenue and increased costs related to this intervention, we computed the stumpage value of a single plant, referring to average stumpage values of ten plants of different species and different age, height and diameter, broadleaf in predominance. 
Table 2.

Average values of lost revenue and higher costs for release of the larger plant computed for individual forest stands in Tuscany

\begin{tabular}{|c|c|c|c|c|c|c|}
\hline Type of forest & Revenue per plant $(€ /)$ & Site class & Age & $\begin{array}{l}\text { Additional cost for } \\
\text { technical surveys }(€)\end{array}$ & $\begin{array}{l}\text { Average value per } \\
\text { plant }(€)\end{array}$ & $\begin{array}{l}\text { Forest regional surface } \\
\text { (hectare) }\end{array}$ \\
\hline Douglas fir & 58.65 & 1 & 50 & 47.52 & 88.02 & \multirow{3}{*}{10,240} \\
\hline Douglas fir & 40.08 & 3 & 50 & 47.52 & & \\
\hline Douglas fir & 22.77 & 5 & 50 & 47.52 & & \\
\hline Turkey Oak High Forest (in transition) & 31.55 & 1 & 130 & 47.52 & 75.395 & \multirow{2}{*}{17,048} \\
\hline Turkey Oak High Forest (in transition) & 24.2 & 3 & 110 & 47.52 & & \\
\hline Turkey Oak coppice with standards & 30.39 & & 30 & 47.52 & 77.91 & 220,352 \\
\hline Chestnut & 49.92 & 1 & 48 & 47.52 & 87.865 & \multirow{2}{*}{9120} \\
\hline Chestnut & 30.77 & 2 & 48 & 47.52 & & \\
\hline Sapin & 66.16 & 3 & 120 & 47.52 & 99.21 & \multirow{2}{*}{13,904} \\
\hline Sapin & 37.22 & 4 & 120 & 47.52 & & \\
\hline Beech & 33.84 & 2 & 100 & 47.52 & 79.01 & \multirow{2}{*}{20,384} \\
\hline Beech & 29.14 & & 85 & 47.52 & & \\
\hline Maquis coppice & 18 & & $18-22$ & 47.52 & 65.52 & 110,432 \\
\hline Black pine & 15.93 & 1 & 100 & 47.52 & 63.45 & 20,496 \\
\hline Pine Maritime & 8.79 & 2 & 60 & 47.52 & 56.31 & 60,928 \\
\hline
\end{tabular}

As we have just said for the a) i measures, funding measures will be provided in seven years, so it is possible that the landowners may anticipate some of the costs; at the same time it is possible that the Regional Administration may grant an advance payment to the landowners when the intervention is performed at the end of the period. The eventual interests, active or passive, that might arise assume irrelevant values and so are not inserted in the calculation. Moreover, it is necessary to distinguish between landowners applying the measure at the beginning or at the end of the period considered; normally this behavior involves much higher costs for testing operations (verification) of forest setting, much higher than the currency interest on advances.

To the loss of income determined above must be added the costs involved in the relief map necessary for the detection and mapping of plants. These costs are based on current professional tables. The amounts, shown in Tables 3 and $\mathbf{4}$, consider time needed for geo-referencing or processing the plants detected.

If we add to this also the loss of interest on forest capital (considering the adoption of an interest rate of $3 \%$ ) because of no forest utilization, for the seven-year duration of the measure, we obtain an additional cost of $€ 1.80$ for plant.

The following Table 5 shows the computation of lost revenue and higher costs for each plant released in according to the baseline. This value is composed of a fixed part, which consists of the geo-referenced survey of the twenty plants to be released according to the baseline, and by a variable part represented by the number of plants left in accordance with the following formula (4):

$$
\text { Lost revenue and higher costs }=\mathrm{A}+\mathrm{xB}+\mathrm{xC}+\mathrm{xD}
$$

where $x$ is the number of plants released in excess of 20 and $A$, $\mathrm{B}, \mathrm{C}, \mathrm{D}$ are the kinds of costs as well as represented and calculated in Table 5.
Table 3.

Loss of revenue for the release of a mixed group of plants.

\begin{tabular}{cccc}
\hline Timber assortments & $€ /$ ton & tons & Totale Value $(€)$ \\
\hline Logs $>20 \mathrm{~cm}$ & 150 & 0.35 & 53.10 \\
bolts & 80 & 0.96 & 77.09 \\
firewood & 30 & 0.15 & 4.46 \\
& & & 134.65
\end{tabular}

Loss revenue single plant

Value single plant

13.46

Table 4.

Costs and lost revenue for each plant issued in excess of the first 20 plants.

\begin{tabular}{lc}
\hline \multicolumn{1}{c}{ Type of costs } & $€$ \\
\hline A) Cost of geo-referencing of the first 20 plants & 76.28 \\
$\begin{array}{lc}\text { B) Cost of geo-referencing of each plant in excess of the } \\
\text { initial } 20\end{array}$ & 0.63 \\
C) Financial loss of each individual plant & 13.46 \\
& 1.8 \\
\hline & 92.17 \\
\hline
\end{tabular}


Table 5.

Costs for 5 and 10 plants additional to baseline.

\begin{tabular}{lcc}
\hline \multicolumn{1}{c}{ Coltural operation } & $\begin{array}{c}\text { No. } 5 \\
\text { plants }(€)\end{array}$ & $\begin{array}{c}\text { No. 10 } \\
\text { plants }(€)\end{array}$ \\
\hline $\begin{array}{l}\text { a) Georeferencing cost of of the first } \\
\text { twenty plants }\end{array}$ & 76.28 & 76.28 \\
$\begin{array}{l}\text { b) The cost of geo-referencing of the plant } \\
\text { in excess of the initial 20 } \\
\text { c) Financial loss to individual plant }\end{array}$ & 3.13 & 6.25 \\
$\begin{array}{l}\text { d) Loss of interest on investments reported } \\
\text { single plant } \quad \text { Total }\end{array}$ & 9.01 & 134.64 \\
$\quad$ Lost income and higher costs per year & 22.25 & 33.03 \\
\hline
\end{tabular}

The cost defined for a single plant released beyond the prescribed twenty is forecast at $€ 92.17$. Over the next seven years, therefore, we must consider the annual value of lost revenue and higher costs totaling the amount $€ 22.25$ when five plants are released and $€ 33.60$ if there are 10 plants.

Another forest environmental commitment that we have analyzed is "Cleaning and mowing grass and shrub vegetation in the forests and other measures for the protection of structural biodiversity".

b) Cutting the shrubs of the open areas within forests or wooded areas treated when included in or adjacent to a forest.

Baseline: There are no obligatory practices.

Effect on revenue component $\left(\mathrm{R}^{*}\right)$ : There are no effects on revenues.

Effect on cost component $\left(\mathrm{C}^{*}\right)$ : costs of scrub removal and mowing.

The action involves scrub clearance in the first year commitment and at least 3 other interventions of this type during the remaining time of commitment; the work must be performed every other year (the third, fifth and seventh year of commitment).

Table 7 shows the variables and the related costs for mechanical mowing per hectare.

The calculation reported above of machine hours and labor hours accrued has been achieved on the basis of the information contained in the price list for regional operations and forestry workers (Regione Toscana, 2008).

Therefore, the costs per hectare of cultivation operations amounted to $€ 604.10$ for the scrub clearance on land moderately invaded by grasses and shrubs and $€ 302.05$ for clearance on lands invaded by low weeds.

The annual amount of lost revenue and higher costs (3 moderate clearings); 3 years are considered, amounting to $€ 215.75$ per year ((€ 604.10 + (302.05 × 3): 7).

Therefore, the amount of lost revenue and higher costs is higher than expected, i.e., $€ 200.00$ per hectare.

c) Debris management processing

Obligation of removing and/or shredding, with subsequent distribution of wood debris on the ground; it is forbidden to burn the waste on site.

Baseline: obligation of splitting logs

Effect on revenue component $\left(\mathrm{R}^{*}\right)$ : increase in revenues derived from sale of timber assortments.

Effect on cost component $\left(\mathrm{C}^{*}\right)$ : chipping/shredding costs of waste material per hectare and distribution on site.

The action requires that the scraps must be taken away or chipped and/or shredded (manually or mechanically), with subsequent distribution on the ground: it is forbidden to burn them except for reasons of plant pathology (on the area where forest operations are carried out).

For the calculation of lost revenue and higher costs we first made an appraisal of the average quantity of waste material per hectare. Then, by calculating the average productivity of a chipper, we computed the relative cost per hectare for the chipping of slash determined before. Therefore for the calculation of the quantities of slash per hectare reflecting the species, type of management and age of the plant we referred to the studies (Bernetti, 1987; Spinelli, 1999; Bernetti, et al., 2004). At the same time to evaluate the cost of chipping, according to its average efficiency, the experience was sought from industry experts.

The following Table 7 shows the chipping cost per hectare of the waste material left on site (inclusive of the forest operation of wood material), for the most common types of forest in Tuscany classified according to species, class fertility and age. The result includes the cost of distribution of wood chips on the ground.

Chipping is convenient in situations where mechanical equipment has easy access and where there is a viable market for wood chips. This is true in particular where the orographic conditions, the forest road system and the market determine advantages and disadvantages for the processing of forest residuals.

Normally it is impossible in each individual request that the

Table 6.

Cost of tending.

\begin{tabular}{lcc}
\hline & Hours/Hectare $€ /$ Hour & $€ /$ Total \\
\hline $\begin{array}{l}\text { Mechanical chaining carried out on field medium invaded by grasses and shrubs, accommodation } \\
\text { and removal of debris }\end{array}$ & 10.0 \\
Tractor equipped and specialized worker & 604.1 \\
Mechanical chaining carried out on field low invaded by grasses and shrubs, accommodation and \\
removal of debris
\end{tabular}


Table 7.

Cost of collection, chipping and spreading of slash.

\begin{tabular}{|c|c|c|c|c|c|c|}
\hline ID & Species & $\begin{array}{l}\text { Cost of chpping per } \\
\text { hectare (€/hectare) }\end{array}$ & $\begin{array}{l}\text { Costs chipping and split of slash } \\
\text { left on the ground per } € / \text { hectare }\end{array}$ & $\begin{array}{l}\text { Costs spreading } \\
\text { per hectare }(€)\end{array}$ & $\begin{array}{l}\text { Sale chips } \\
(€ / \text { hectare })\end{array}$ & $\begin{array}{l}\text { Costs chips net } \\
\text { revenue }(€)\end{array}$ \\
\hline 1 & Maritime pine & 1317 & 1129 & 270 & 1981 & 735 \\
\hline 2 & Maritime pine & 785 & 673 & 270 & 1180 & 548 \\
\hline 3 & Maritime pine & 943 & 808 & 270 & 1418 & 603 \\
\hline 4 & Douglas fir & 2131 & 1826 & 270 & 3204 & 1023 \\
\hline 5 & Black pine & 997 & 855 & 270 & 1500 & 622 \\
\hline 6 & Black pine & 777 & 666 & 270 & 1168 & 545 \\
\hline 7 & Black pine & 521 & 446 & 270 & 783 & 454 \\
\hline 8 & Black pine & 1334 & 1143 & 270 & 2005 & 742 \\
\hline 9 & Black pine & 1070 & 917 & 270 & 1609 & 648 \\
\hline 10 & Black pine & 877 & 752 & 270 & 1319 & 580 \\
\hline 11 & Black pine & 919 & 788 & 270 & 1382 & 595 \\
\hline 12 & Black pine & 778 & 667 & 270 & 1170 & 545 \\
\hline 13 & Black pine & 635 & 544 & 270 & 955 & 494 \\
\hline
\end{tabular}

Table 8.

Summary table of lost revenue and higher costs calculated.

\begin{tabular}{ccc}
\hline Kind of forest-environment commitments & $€ /$ hectare per \\
Year & \\
\hline
\end{tabular}

1) Selection of species subject to utilization.

a) Release of one or more plants per hectare selected among older species and/or greater diameter and wood value, identified according to the criteria defined in Art. No 12 of DPGR 2003/48/Tuscan Region.

b) Release of at least 5 plants per hectare selected among older species and/or greater diameter and wood value, identified according to the criteria defined in Art. No 12 of DPGR 2003/48/Tuscan Region.

$€ 10.39$ per plant

$€ 22.25$ per 5 plants

$€ 29.55$

$€ 59.76$

$€ 75.70$

2) Cleaning and mowing grass and shrub vegetation in the forests and other measures for the protection of biodiversity structural.

Cutting the shrubs in the open areas within forests or wooded areas treated when covered by or neighbouring to a forest.

$€ 200.0$

3) Waste forest management processing.

Duty of removal or, alternatively, exist the obligation to chipping and/or shredding, with subsequent distribution of wood debris on the ground; it is also forbidden to burn the debris on the ground the ground.

4) Impact of forest utilization on soil, shrubbery, on the regeneration and wildlife.

Use for yarding and hauling by pack animals, crane cable and chute instead of mechanical means.

$€ 104.10$

additional cost of chipping be in regulation, when this would not result as profitable because its costs are not compensated. To this end, in determining the entity of lower revenues and higher costs, an analysis of the Tuscan territory was made which took into account the variables described above. The result of this analysis allowed us to identify an area representa- 
tive sample of the context within which it is convenient to chip, remove the chips and sell $70 \%$ of these.

For the remaining $30 \%$ of the residual material, not easily transportable and therefore not sellable, there is expected a partially mechanical chipping and the subsequent homogeneous distribution on the ground; if work with the chipper is not possible, the other part of this can be split into pieces of maximum length of 1 meter and maximum diameter of $5 \mathrm{~cm}$. The average cost of chipping was considered to be equal to $€ 7$ per cubic meter of timber used. The average cost of chipping and shredding is considered equal to $€ 14$ per cubic meter of timber used.

Despite the wide variability of costs shown in Table 8, giving an average value per hectare is justified; in fact, applying the intervention for each specific situation does not seem warranted, considering that detection and control of costs is often greater than the premium paid. Furthermore, this variability reflects the characteristics of the ownership of the forests, often fragmented and scattered throughout the territory. It follows that the average amount of lost revenue and higher cost received by the individual beneficiary of the intervention is broadly appropriate to the forest structure, itself also quite variable. The average cost of the project is equal to $€ 625.54$ per hectare. The annual value of lost revenue and higher costs will, therefore, amount to $€ 89.36$ per hectare.

At the conclusion of the detailed examination of some of the measures provided by Regulation 225 (Council Regulation (EC) No. 1698/2005 and adopted by the Region of Tuscany, we present in one table (Table 8) the amount of lost revenue and higher costs considering all the measures established by the Regulation.

\section{Conclusion}

Our study was limited to defining a methodology for determining compensation that can completely cover the higher costs and lower revenues (as required by the EU). It would be extremely useful and interesting to complete this research by analyzing the impact and effectiveness of each single action on the provision of public goods and externalities. The choice of the single actions financed by the Region of Tuscany follows more a political path then a technical one (problems in the decision process at national scale). The constraint imposed by the European Community to pay only the higher costs and lower revenues (computed on the basis of market prices) undervalues the production of public goods and prevents their real development (problems in the political instruments adopted at European scale).

\section{REFERENCES}

Bauer J., \& Corredor, H. G. (2006). International forest sector institutions and policy instruments for Europe: A source book. UNECEFAO: United Nations Publications.

Bernetti, G. (1987). I boschi della Toscana. Quaderni di Monti e Boschi, Giunta Regionale Toscana: Edagricole.

Bernetti, I., Fagarazzi, C., \& Fratini, R. (2004) A methodology to analyze the potential development of biomass energy sector: An application in Tuscany. Forest Policy and Economics, 6, 415-432. doi:10.1016/i.forpol.2004.03.018

Ciancio, O., \& Nocentini, S. (2004). Il bosco ceduo. Firenze: Accademia Italiana di Scienze Forestali.

Hippoliti, G. (1997). Appunti di meccanizzazione forestale. Florence: Studio Editoriale Fiorentino.

ISAFA (1987). Tavole stereometriche ed alsometriche dei boschi italiani. Trento.

Italian Ministry of Agriculture, Food and Forestry (2009). Policy and good forest management practices baseline measures for the implementation of forestry and environmental. Rete Rurale Nazionale, Task Force Foreste.

Regione Toscana (2008). Modifiche ed integrazioni al prezzario regionale per interventi ed opere forestali di cui alla. Bollettino ufficiale della regione Toscana, 55 .

Sherwood (2012). www.rivistasherwood.it/tecniko-pratiko

Spinelli, R. (1999). Environmental and socio-economic impacts of using excavators and backhoe loaders as base machines in forest. In Proceedings from the first meeting of a concerted action FAIR-CT 98-3381 (pp. 109-116). Garpenberg, 13-17 December 1999. 